IZA DP No. 4247

Structural Change out of Agriculture:

Labor Push versus Labor Pull

Francisco Alvarez-Cuadrado

Markus Poschke

June 2009 


\title{
Structural Change out of Agriculture: Labor Push versus Labor Pull
}

\author{
Francisco Alvarez-Cuadrado \\ McGill University \\ Markus Poschke \\ McGill University \\ and IZA
}

Discussion Paper No. 4247

June 2009

IZA

P.O. Box 7240

53072 Bonn

Germany

Phone: +49-228-3894-0

Fax: +49-228-3894-180

E-mail: iza@iza.org

\begin{abstract}
Any opinions expressed here are those of the author(s) and not those of IZA. Research published in this series may include views on policy, but the institute itself takes no institutional policy positions.

The Institute for the Study of Labor (IZA) in Bonn is a local and virtual international research center and a place of communication between science, politics and business. IZA is an independent nonprofit organization supported by Deutsche Post Foundation. The center is associated with the University of Bonn and offers a stimulating research environment through its international network, workshops and conferences, data service, project support, research visits and doctoral program. IZA engages in (i) original and internationally competitive research in all fields of labor economics, (ii) development of policy concepts, and (iii) dissemination of research results and concepts to the interested public.
\end{abstract}

IZA Discussion Papers often represent preliminary work and are circulated to encourage discussion. Citation of such a paper should account for its provisional character. A revised version may be available directly from the author. 


\section{ABSTRACT \\ Structural Change out of Agriculture: Labor Push versus Labor Pull}

The process of economic development is characterized by substantial rural-urban migrations and a decreasing share of agriculture in output and employment. The literature highlights two main engines behind this process of structural change: (i) improvements in agricultural technology combined with the effect of Engel's law of demand push resources out of the agricultural sector (the "labor push" hypothesis), and (ii) improvements in industrial technology attract labor into this sector (the "labor pull" hypothesis). We present a simple model that features both channels and use it to explore their relative importance. We evaluate the U.S. time series since 1800 and a sample of 13 industrialized countries starting in the 19th century. Our results suggest that, on average, the "labor pull" channel dominates. This contrasts with popular modeling choices in the recent literature.

JEL Classification: $\quad 011,041$

Keywords: $\quad$ growth, structural change

Corresponding author:

Francisco Alvarez-Cuadrado

Department of Economics

McGill University

855 Sherbrooke Street West

Montreal, QC

Canada H3A 2T7

E-mail: francisco.alvarez-cuadrado@mcgill.ca

\footnotetext{
We gratefully acknowledge the outstanding research assistance provided by Jan-Francois Grabowiecki and the constructive comments by John Galbraith, Douglas Gollin, Gregor Smith, Jaume Ventura and by seminar participants at McGill University, Florida International University, GRADE, the Université de Montréal macro brownbag, Université Laval, the 43rd Annual Conference of the Canadian Economics Association (Toronto 2009) and the XXXIII Symposium of Economic Analysis (Zaragoza 2008). We also thank Talan Iscan for sharing his data on the U.S. time series with us.
} 
"It is quite wrong to try founding a theory on observable magnitudes... It is the theory which decides what we should observe." Albert Einstein, quoted by Heisenberg (1972, p. 63).

\section{Introduction}

The process of economic development is always and everywhere characterized by substantial reallocations of resources out of agriculture. While most economists agree that this structural transformation has been driven by productivity increases, there is no consensus on whether technological progress in manufacturing or in agriculture has been more important. Yet, given the continuing importance of the agricultural sector in today's poor economies, it is crucial to have a proper understanding of the historical determinants of structural change. To address this, we propose a simple model that encompasses both sources of structural change to show how to identify their relative importance in the data. We use this model to explore the historical experience of 13 countries that have completed their process of structural reallocation, using data from the 19th century onwards.1.

Already Clark (1940), Kuznets (1966) and Chenery and Syrquin (1975) documented the process of structural transformation: the fall in the share of agriculture in output and employment that accompanied long-run increases in income per capita. As an example, in 1800, the U.S. economy employed around three fourths of its labor force in the agricultural sector. The sector accounted for more than half of total output. Two hundred years later, only $2.5 \%$ of the labor force remained in the agricultural sector and the share of agricultural production in GDP was below 1\%. Over these two centuries, U.S. output per capita increased more than 25 times.

Although development economists and economic historians have long been interested in this process of structural transformation, there has been and still is substantial debate about the relative roles technological progress in the agricultural and the manufacturing sectors played in the process, with classical and more recent contributions on both sides.

On the one hand, there is a continuing tradition that places the emphasis of the transformation on the manufacturing sector. Lewis (1954) presents a model where capital accumulation in the modern sector raises urban wages and attracts surplus labor from the

\footnotetext{
${ }^{1}$ In this paper, we use the term "structural change" in a narrow sense to refer exclusively to movements of resources out of the agricultural sector. Moreover, to keep the prose simple, we will use the terms "modern sector" and "manufacturing sector" to refer to the entire non-agricultural sector.
} 
agricultural sector. Reinvestment of profits keeps the process going. Similarly, Harris and Todaro (1970) present a two sector model in which rural-urban migration results from positive differences between the expected urban (industrial) real income and agricultural product per worker. Both theories suggest that technological progress and investment in manufacturing raise urban incomes and drive the process of structural change. In this view, increasing industrial wages attract low-paid or underemployed labor from agriculture into manufacturing. Following Gylfason and Zoega (2006) we refer to this as the "labor pull" hypothesis. Hansen and Prescott (2002) model a similar mechanism and conclude that "the (modern) technology must improve sufficiently so that it ultimately becomes profitable to shift resources into this sector".

On the other hand, some scholars consider agricultural productivity the main driver of structural change. Nurkse (1953) argues that "everyone knows that the spectacular industrial revolution would not have been possible without the agricultural revolution that preceded it". Rostow (1960) identifies increases in agricultural productivity as a necessary condition for a successful take-off. These authors suggest that improvements in agricultural technology allow solving the "food problem" (Schultz 1953), so that resources can be released from the agricultural to the manufacturing sector. We refer to this as the "labor push" hypothesis. Recently, Gollin, Parente and Rogerson $(2002,2007)$ provide a modern formalization of these ideas. In their words, "improvements in agricultural productivity can hasten the start of industrialization and, hence, have large effects on a country's relative income. A key implication of the model is that growth in agricultural productivity is central to development." Productivity growth in agriculture also acts as the main driver of the structural transformation in Ngai and Pissarides (2007).

Our objective is to provide empirical evidence on the relative importance of the "push" and "pull" hypotheses. We present a simple model close to Matsuyama (1992) and to Kongsamut, Rebelo and Xie (2001) that is consistent with the two crucial observations associated with the process of structural change: a secular decline in the share of the labor force devoted to agriculture and a decreasing weight of agricultural output in national product. Our model captures both sources of structural change highlighted in the literature: improvements in agricultural technology combined with Engel's law of demand shift resources to the industrial sector, and improvements in manufacturing technology increase manufacturing wages, pulling labor into that sector. We use this framework to assess the effects of increases in agricultural and manufacturing productivity on key 
observable variables. Both hypotheses lead to qualitatively similar behavior of labor allocations, the share of agriculture in GDP, and wages. They differ in their predictions for the evolution of the relative price of manufactures relative to agricultural goods. Hence, data on the relative price allow identifying which sector is the main engine of the structural transformation. In this sense, our exercise follows a long tradition in economics that uses changes in relative prices to infer changes in productivity. A recent example is Greenwood, Hercowitz and Krusell (1997).

We then explore the determinants of structural change using data on relative prices and on agricultural labor shares in two samples: the U.S. time series since 1800 and a long panel of 13 industrialized countries starting in the 19th century. Since for the U.S., estimates of sectoral productivities are available, the first exercise allows us to confirm the validity of our basic identifying strategy. In line with the model predictions, the relative price is almost a mirror image of relative productivity. For the larger sample, not all of the data required to compute sectoral productivities is available. In these circumstances, our parsimonious approach that relies on the relative price provides important insights that could not be obtained otherwise.

There are three main findings. Firstly, there is a lot of heterogeneity; both channels play a role. For instance, in the case of the U.S. it is very clear that the "labor pull" channel dominated before World War I, with the "labor push" channel taking over after World War II (this period has also been dubbed the Green Revolution). Secondly, on average, increases in non-agricultural productivity slightly outpaced those in agricultural productivity, pointing to the "labor pull" channel as a somewhat more important driver of structural change overall. Finally, we find that the decline in the agricultural labor share is larger when the productivity of manufacturing increases relative to that of agriculture than the other way round. This holds at all stages of the structural transformation.

The main contribution of our paper hence is to provide insights about the historically important drivers of structural change. Our results have important implications for modeling that process. In particular, models of structural change that rely on faster productivity growth in agriculture such as Ngai and Pissarides (2007) seem to be at odds with most of the the pre-World War II evidence. Moreover, models of structural change that restrict non-homotheticities in preferences to food consumption, such as Gollin, Parente and Rogerson (2002), seem to miss non-agricultural technological progress as an important driver of structural change. As a consequence, our results cast some doubt on some of 
the estimates and policy recommendations derived using modeling strategies that neglect the crucial role played by non-agricultural productivity in the process of structural change and economic development. Given the continuing importance of the agricultural sector in today's poor economies and its impact on aggregate productivity differences documented by Caselli (2005), Temple and Woessmann (2006) and Restuccia, Yang and Zhu (2008), among others, it is crucial to have a proper understanding of the historical determinants of structural change.

The paper is organized as follows. Section 2 sets out the basic model and explores the implications of increases in agricultural and manufacturing productivity. Section 3 evaluates our model against the U.S. experience. Section 4 explores the determinants of structural change in a long panel of 13 industrialized countries. The conclusions are summarized in Section 5, while the Appendices provide some technical details and data descriptions.

\section{Agricultural Push vs. Industrial Pull in a simple model of structural change}

We consider a closed economy that consists of two sectors: a traditional sector devoted to the production of agricultural goods and a modern sector that produces industrial commodities and services. The size of the labor force is constant and normalized to 1 . Both production technologies exhibit weakly diminishing returns to labor,

$$
\begin{gathered}
Y_{t}^{M}=M F\left(L_{t}^{M}\right), \quad M>0, F^{\prime}>0, F^{\prime \prime} \leq 0 \\
Y_{t}^{A}=A G\left(L_{t}^{A}\right), \quad A>0, G^{\prime}>0, G^{\prime \prime} \leq 0,
\end{gathered}
$$

where $L_{t}^{M}$ and $L_{t}^{A}=1-L_{t}^{M}$ are the amounts of labor employed in manufacturing and in agriculture respectively, and $M$ and $A$ denote the levels of technology in the two sectors. For the moment, we assume that both technology parameters are constant.

As in Matsuyama (1992), labor can move freely across sectors. Then, competition 
between firms in both sectors ensures that a non-arbitrage condition holds:2

$$
w_{t}^{A}=A G^{\prime}\left(1-L_{t}^{M}\right)=p_{t} M F^{\prime}\left(L_{t}^{M}\right)=w_{t}^{M},
$$

where $w_{t}^{A}$ is the real wage in the traditional sector and $w_{t}^{M}$ that in the modern sector. $p_{t}$ is the relative price of the manufacturing good which can be expressed as

$$
p_{t}=\frac{A G^{\prime}\left(1-L_{t}^{M}\right)}{M F^{\prime}\left(L_{t}^{M}\right)} .
$$

Consumers are identical, infinitely lived, and inelastically supply their labor endowment. Their preferences are given by

$$
U\left(c_{t}^{A}, c_{t}^{M}\right)=\alpha \ln \left(c_{t}^{A}-\gamma\right)+\ln \left(c_{t}^{M}+\mu\right), \quad \alpha, \gamma, \mu>0,
$$

where $c_{t}^{A}$ and $c_{t}^{M}$ denote individual consumption of food and manufactures, respectively, and $\alpha$ the relative weight of food in preferences. These preferences are non-homothetic for two reasons. First, we introduce a subsistence level of food consumption, $\gamma$. As a result, the income elasticity of food demand is below one, in line with the evidence on the universality of Engel's law known at least since Houthakker (1957). This feature of preferences has long been emphasized in the literature on sectoral reallocation (Matsuyama 1992, Laitner 2000, Caselli and Coleman 2001, Gollin et al. 2002). Second, we assume that the income elasticity of non-agricultural goods is greater than one. Following Kongsamut et al. (2001) we can interpret $\mu$ as an exogenous endowment of non-agricultural goods, possibly resulting from home production 3 Finally, we assume that the level of agricultural productivity is high enough so that our economy operates above the subsistence level of food,

$$
A G(1)>\gamma
$$

\footnotetext{
${ }^{2}$ The extent of integration of the rural labor market with the rest of the economy is a topic of debate. While some development economists argue that it is low, Magnac and Postel-Vinay (1997) provide evidence from 19th century France that "migration between industry and agriculture was quite sensitive to relative wages in the two sectors" and that firms took this into account in their decisions. They also find that wages were similar in the two sectors. Moreover, our qualitative results are robust to the introduction of quadratic migration costs à la Krugman (1991).

${ }^{3}$ For instance, clothes can be washed using a washing machine (a component of $c_{M}$ ) or by hand (home production). Our specification can thus be interpreted as modeling home production in reduced form, similar to Kongsamut et al. (2001) and Duarte and Restuccia (2010). In Appendix A, we introduce a generalized CES specification that yields identical results when $\mu=0$. Nonetheless we believe that our exposition is clearer under (2).
} 
The representative household chooses his consumption bundle to maximize the present value of (2), discounted at a rate $\rho>0$, subject to the budget constraint

$$
w_{t}^{A}\left(1-l_{t}^{M}\right)+w_{t}^{M} l_{t}^{M}=c_{t}^{A}+p_{t} c_{t}^{M}
$$

where $l_{t}^{M}$ represents time spent working in the modern sector. $4^{4}$ Together with (4), the optimality conditions associated with this program are

$$
\begin{gathered}
\frac{\alpha}{c_{t}^{A}-\gamma}=\lambda \\
\frac{1}{c_{t}^{M}+\mu}=\lambda p_{t},
\end{gathered}
$$

where $\lambda$ is the shadow value of an additional unit of income. Optimizing households equate the marginal rate of substitution between the two consumption goods to the relative price. Combining these two equations, the individual demand for the agricultural good satisfies $c_{t}^{A}=\gamma+\alpha p_{t}\left(c_{t}^{M}+\mu\right)$. Aggregating across households and using upper case letters for aggregate variables, this becomes

$$
C_{t}^{A}=\gamma+\alpha p_{t}\left(C_{t}^{M}+\mu\right)
$$

In equilibrium, all output from both sectors is consumed, so $C_{t}^{A}=Y_{t}^{A}$ and $C_{t}^{M}=Y_{t}^{M}$. Combining the market clearing condition with (1) and (5) yields the following relation for the allocation of labor between sectors.

$$
\frac{\gamma}{A}=G\left(1-L_{t}^{M}\right)-\alpha \frac{G^{\prime}\left(1-L_{t}^{M}\right)}{F^{\prime}\left(L_{t}^{M}\right)}\left(F\left(L_{t}^{M}\right)+\frac{\mu}{M}\right)=\phi\left(L_{t}^{M}, M\right)
$$

where

$$
\phi\left(L_{t}^{M}, \bar{M}\right)<\phi(0, \bar{M})=G(1) ; \quad \phi_{L_{t}^{M}}<0 ; \phi_{M}>0,
$$

where $\phi_{x}$ denotes the partial derivative of $\phi$ with respect to the variable $x$. Given (3), equation (6) has a unique solution that determines the level of employment in the nonagricultural sector.

To obtain the effect of productivity increases on the sectoral allocation, differentiate (6) with respect to the productivity parameters:

$$
\begin{aligned}
& \frac{\partial L^{M^{*}}}{\partial A}=-\frac{\gamma}{A^{2} \phi_{L^{M}}^{*}}>0 \\
& \frac{\partial L^{M^{*}}}{\partial M}=-\frac{\phi_{M}^{*}}{\phi_{L^{M}}^{*}}>0,
\end{aligned}
$$

\footnotetext{
${ }^{4}$ Since we abstract from capital accumulation, our problem is simply a sequence of static problems.
} 
where equilibrium choices are denoted by ${ }^{*}$. Productivity increases in either sector lead to flows of labor out of agriculture. Our model thus captures the two engines behind the large reallocation of labor out of agriculture that were highlighted in the introduction. As in Matsuyama (1992) and Gollin et al. (2002), increases in the level of agricultural productivity push labor out of the agricultural sector: the "labor push" effect discussed by Nurkse (1953) and Rostow (1960). But additionally, as in Hansen and Prescott (2002), improvements in the level of technology in the industrial sector pull labor out of the traditional sector, increasing manufacturing employment: the "labor pull" effect stressed by Lewis (1954) and Harris and Todaro (1970). The income elasticities of demand for agricultural and non-agricultural commodities lie behind these two effects. Notice that if $\gamma=0$ the labor allocation is independent of the level of agricultural technology and if $\mu=0$ the labor allocation is independent of the level of technology in the non-agricultural sector.

Our model is also consistent with the second stylized fact of structural change, the secular decline of the share of agriculture in GDP. Consider the ratio of non-agricultural to agricultural output,

$$
\frac{p_{t} Y_{t}^{M}}{Y_{t}^{A}}=\frac{G^{\prime}\left(1-L_{t}^{M}\right)}{F^{\prime}\left(L_{t}^{M}\right)} \frac{F\left(L_{t}^{M}\right)}{G\left(1-L_{t}^{M}\right)} .
$$

This expression increases in $L_{t}^{M}$, the share of labor employed in non-agricultural production. Hence, increases in productivity in either sector reduce the share of agriculture not only in employment but also in output.

Finally, we can evaluate the effects of technological change on the relative price of manufactures. Using (1), (5), (7) and (8), we find the following comparative statics results for the relative price,

$$
\begin{gathered}
\frac{\partial p^{*}}{\partial A}=\frac{\left[G^{\prime}(.)-A G^{\prime \prime}(.) \frac{\partial L^{M^{*}}}{\partial A}\right] F^{\prime}(.)-A G^{\prime}(.) F^{\prime \prime}(.) \frac{\partial L^{M^{*}}}{\partial A}}{M\left[F^{\prime}(.)\right]^{2}}>0 \\
\frac{\partial p^{*}}{\partial M}=-\frac{A G^{\prime}(.) \frac{\partial L^{M^{*}}}{\partial M}}{\alpha[M F(.)+\mu]}-\frac{\left(A G^{\prime}(.)-\gamma\right)\left(F(.)+M F^{\prime}(.) \frac{\partial L^{M^{*}}}{\partial M}\right)}{\alpha[M F(.)+\mu]^{2}}<0 .
\end{gathered}
$$

We can use this simple framework with only labor and costless reallocation between sectors to explore the empirical implications of the labor-push and labor-pull hypotheses. Both hypotheses are associated with migrations from the countryside to the manufacturing 
centers and with a declining weight of agriculture in national product. Furthermore, both hypotheses are associated with increases in rural and urban wages. But while increases in agricultural productivity, $A$, are associated with increases in the relative price of the nonagricultural good, increases in the level of productivity in the modern sector, $M$, reduce the relative price of non-agricultural goods. Thus, while the evolution of wages, labor allocations or sector output shares provides little information to discriminate between the two hypotheses, the behavior of relative prices gives crucial insights about the relative roles of the agricultural revolution and the industrial revolution in the process of structural change that started in Britain more than two centuries ago. In this sense, our exercise follows a long tradition in economics that uses changes in relative prices to infer changes in productivity. A recent example is Greenwood et al. (1997).

Finally, we turn to explore the implications of our model in the presence of continuous technological change in both sectors, most likely the empirically relevant case. Denoting the instantaneous growth rates of agricultural and non-agricultural productivity by $\hat{A}>0$ and $\hat{M}>0$, respectively, and denoting the change in the share of labor in manufactures by $\dot{L}^{M}$, we use (1) to reach the following expression for the growth rate of the relative price.

$$
\hat{p}=\hat{A}-\hat{M}-\dot{L}^{M}\left[\frac{G^{\prime \prime}\left(1-L_{t}^{M}\right)}{G^{\prime}\left(1-L_{t}^{M}\right)}+\frac{F^{\prime \prime}\left(L_{t}^{M}\right)}{F^{\prime}\left(L_{t}^{M}\right)}\right]>\hat{A}-\hat{M}
$$

As long as there is no technological regress, the last inequality holds. This inequality implies that decreases in the relative price of manufactures are unambiguously associated with faster technological change in the non-agricultural sector, i.e. they indicate that the "labor pull" effect dominates. If the relative price rises, the situation is less clear. An equal increase in both sectors' productivities induces an increase in the relative price of manufactures, resulting from the low income elasticity of demand for food and the high income elasticity of demand for manufactures. So only a strong increase in the relative price is a sign of stronger growth in agricultural productivity, or "labor push". A weak increase in the relative price can well occur in a situation where the productivity in manufacturing has increased by slightly more 5

\footnotetext{
${ }^{5}$ Finally, it is worth noticing that in the presence of international trade, the labor allocation decision is independent of the consumption decision. A small open economy takes the relative price as given and, assuming that labor is mobile across sectors but immobile across countries, the domestic labor allocation is uniquely determined by (1). Given the world relative price, an increase in agricultural productivity then induces a shift of resources to agriculture, the now more productive sector. Increases in manufacturing productivity "pull" labor out of the agricultural sector leading to similar but more intense
} 
In the next two sections, we exploit the implications of our model to explore the sources of structural change using two centuries of U.S. data and a long panel of 13 countries that already completed the process of structural transformation.

\section{A long-term view of structural change in the U.S.}

Although large migrations out of the agriculture began in the UK more than two centuries ago, the U.S. was one of the first countries to complete this process of structural transformation. Furthermore, the wealth and quality of the U.S. data, which besides relative prices includes data on sectoral productivities, makes this country an ideal candidate to evaluate the basic prediction of our model that changes in the relative price reflect changes in relative productivity. In particular, equation (9) implies that if the relative price falls, it must be that productivity in the non-agricultural sector has increased at a faster pace than agricultural productivity.

Figure 1 presents the evolution of the share of employment in agriculture and the relative price of manufactures to agricultural goods for the U.S. from 1800 to 2000 . Over these two centuries, the share of labor employed in agriculture declined from $73 \%$ to barely $2.5 \%$. This decline was monotonic, except for the period of the Great Depression ${ }^{6}$ In contrast, the relative price declined steadily until 1918, then became more volatile until the end of World War II, after which it went on an upward trend. Our model then identifies a change in the main driver behind the process of structural transformation after World War II: the labor pull effect dominates before the war, with the labor push effect taking over later on. This implies that non-agricultural productivity growth outpaced its agricultural counterpart from the beginning of our sample period to World War I, with roles reversing after World War II.

This prediction is consistent with existing estimates of farm and non-farm productivity

migrations than in the closed economy scenario. See Matsuyama $(1992,2009)$ for specific details on the open economy scenario. However, footnote 10 provides evidence that the closed economy assumption seems more appropriate for our sample.

${ }^{6}$ Only recently have real business cycles scholars made an attempt to explain the Great Depression in terms of fully specified stochastic general equilibrium models, see Prescott (1999) and Cole and Ohanian (1999, 2002). Their estimates suggest a 14\% drop in TFP between 1929 and 1934. In the context of the model outlined in the previous section, a drop in TFP in any sector will trigger a process of reverse migration similar to the one observed in the data. 
Figure 1: The share of employment in agricultural and the relative price of manufactures to agricultural goods, U.S., 1820-2000

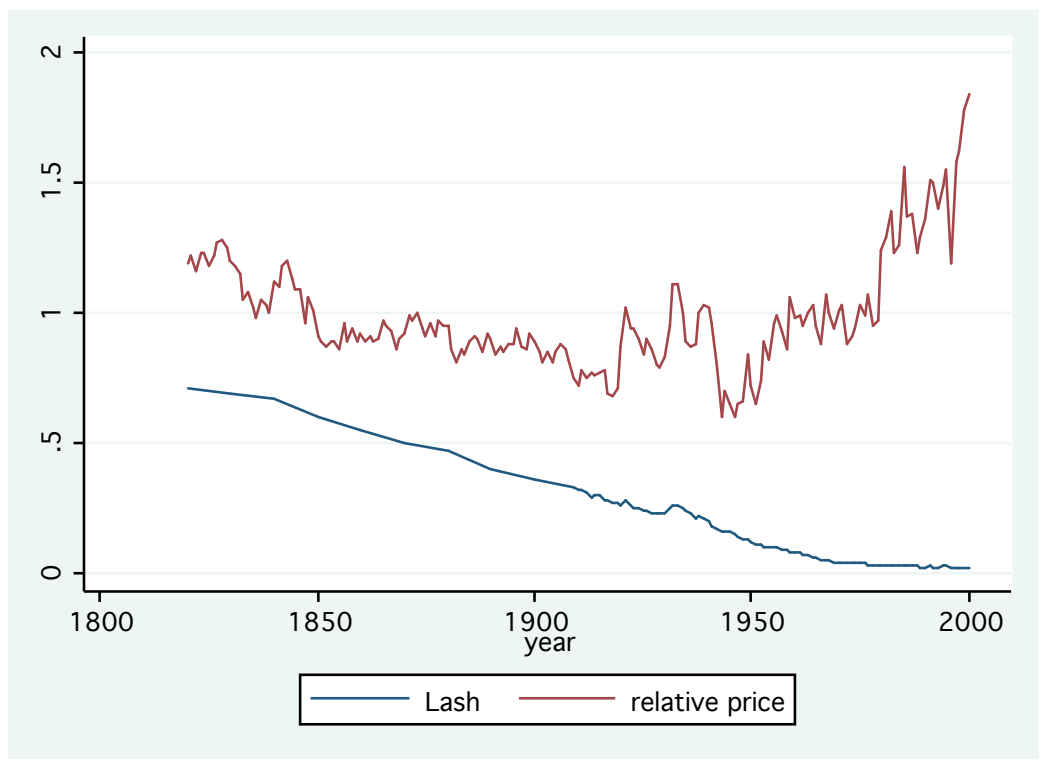

Sources: See Table 5 .

in the U.S.I7 Figure 2 plots the relative price of manufactures to agricultural goods and the relative productivity in the two sectors. Productivity is almost a mirror image of the price. In particular, it is striking to see that while the average growth rate in the non-farm sector outstrips that in the farm sector by $1 \%$ over the period from 1820 to 1948, the trend strongly reverses for the 1948 to 2002 period: in the second half of the twentieth century, average yearly TFP growth in the non-farm sector is $1.4 \%$, compared to $1.7 \%$ in the farm sector. Not surprisingly this latter period, characterized by the rapid adoption of new agricultural technologies, has been known as the period of the "Green Revolution". For instance, after World War II, the adoption rates of tractors and of hybrid corn increased rapidly (Griliches 1957, Olmstead and Rhode 2001), contributing to rapid productivity growth in agriculture. More importantly, the results of this comparison are consistent with the basic prediction of our model and give us confidence to extend our identification strategy based on relative price data to a larger sample of countries where data on sectoral productivity is not readily available.

\footnotetext{
${ }^{7}$ See notes to the figure for sources.
} 
Figure 2: Relative productivity $(2000=1)$ and relative price of non-farm and farm goods, U.S., 1820-2000

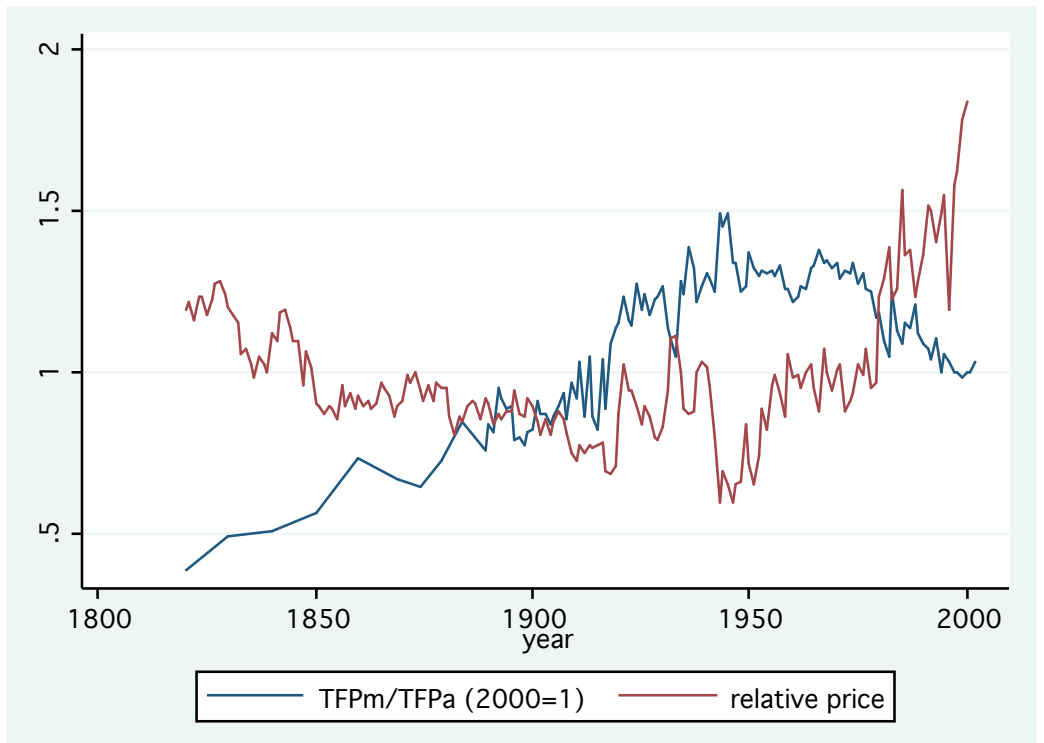

Sources: U.S. farm productivity is from Gallman (1972, Table 7) for 1800-1840, from Craig and Weiss (2000, Table 3) for 1840-1870 (both cited in Dennis and Iscan 2009), from Kendrick (1961, Table BI) for 1869-1948, and from the United States Department of Agriculture (USDA) Economic Research Service, Agricultural Productivity Data Set, http://www.ers.usda.gov/Data/AgProductivity/, for 1948-2000. Non-farm productivity is from Sokoloff (1986, Table 13.9) for 1820-1860 (again cited in Dennis and Iscan 2009), from Kendrick (1961, Table A-XXIII) for 1870-1948, and from the Bureau of Labor Statistics (BLS) Multifactor Productivity Trends - Historical SIC Measures 1948-2002, http: //www.bls.gov/mfp/historicalsic.htm, for 1948-2000.

\section{Historical evidence from some successful transform- ers}

Is the U.S. experience representative? To answer this question, we gather data on labor allocations and relative prices for a sample of 13 countries that have completed their process of sectoral reallocation by the end of the twentieth century. Besides this, data availability determines whether a country is included in our sample.

In contrast to the use of relative productivity series, the use of the relative price has several advantages in terms of data requirements and functional form restrictions. First, the relative price strategy is less demanding in terms of data, giving us more and longer 
series to work with. Computing TFP is a data intensive exercise that, besides the data on labor allocations and prices that we use, requires data on output, other inputs and factor shares. In most cases, these other series are not available. They are also harder to measure and therefore likely less reliable than the data we use. Second, by using relative prices we avoid imposing the stronger restrictions on the production function required to obtain TFP estimates. Finally, our empirical exercise will go beyond the simple inspection of the evolution of the relative price and will attempt to explore the extent to which the labor reallocation responds to changes in relative price to uncover the relative importance of labor push and labor pull in the process of structural change.

\subsection{Data sources and overview}

Our sample consists of 13 countries that have completed the process of structural transformation by the end of the twentieth century and for which we have data on labor allocations and relative prices. For many of these countries, data is available starting in the 19th century. While the number of countries in our sample is not large, the series cover a long span of time, giving a complete picture of the process of structural transformation in these countries. Details on coverage and sources are summarized in Tables 5 and 6 in Appendix B. To abstract from short-run fluctuations and to make figures comparable across data sources, we use five-year moving averages of both variables where data is available at a higher frequency. 8

Figure 3 shows the time paths of the labor share in agriculture for the countries in our sample. The panels group countries with similar experiences. For the U.S., Finland, Sweden, and Japan, our data covers essentially the whole process of structural change, with initial agricultural labor shares in the neighborhood of $80 \%$. For the remaining countries in our sample (UK, Canada, France, Germany, Italy, Belgium, the Netherlands, Spain, and South Korea) the period covered is shorter, but on average our data still captures reallocations that affect more than $25 \%$ of the labor force.

As emphasized by the model, the historical evidence suggests that structural change

\footnotetext{
${ }^{8}$ For some countries where no measure of the price of manufacturing goods is available, we use the GDP deflator relative to the price of agricultural goods. Appendix $[$ shows that this measure changes with changes in relative productivity in the same way as the relative price $p$ does. We focus on manufacturing because this is where resources moved from agriculture. The share of the labor force in services only started to increase when the agricultural share of output was already below 5\%, as Buera and Kaboski (2009) show in their work on the U.S. service sector (see their Figure 1).
} 

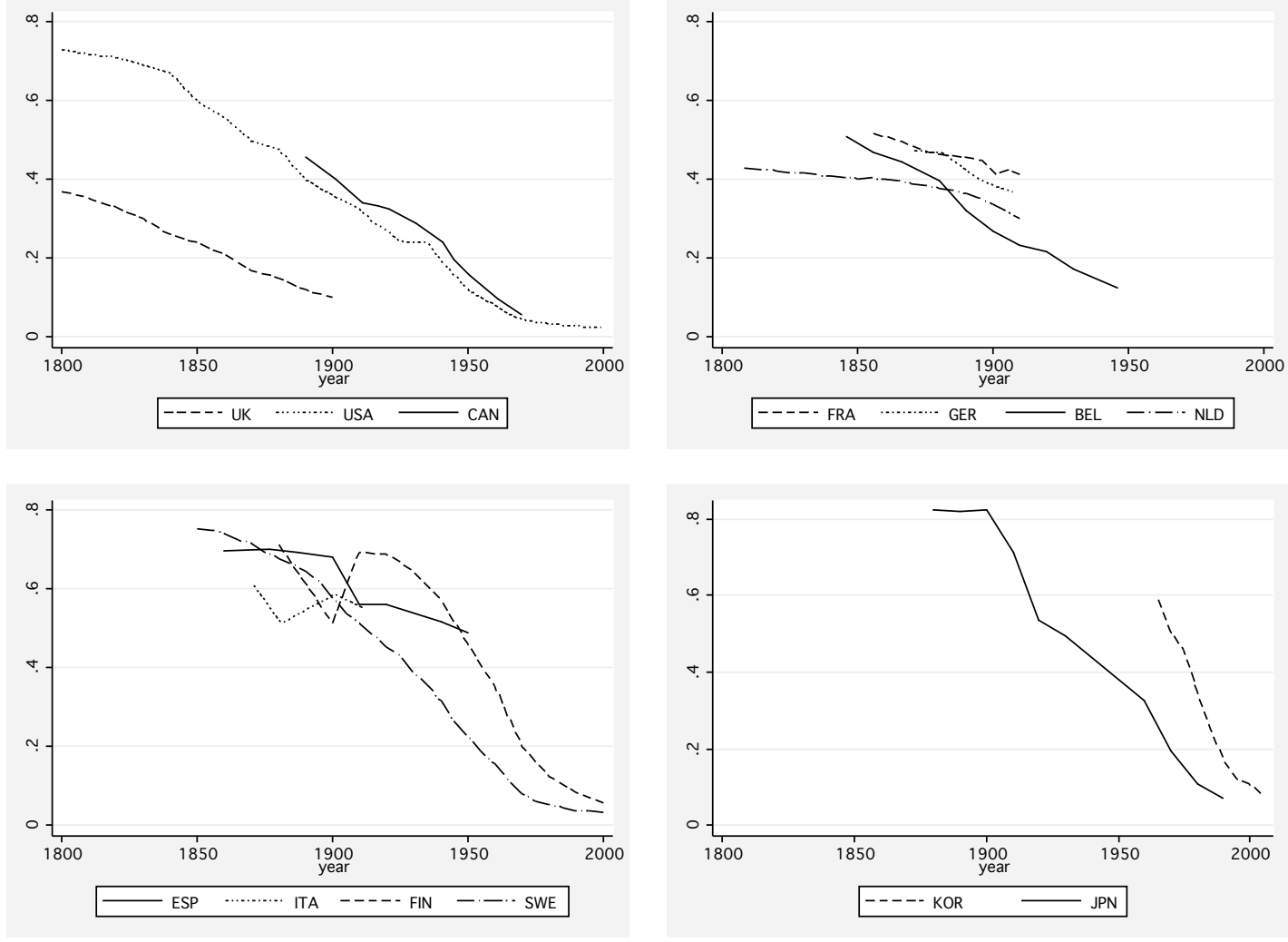

Figure 3: The employment share of agriculture

is a one-way street. Increases in the labor share in agriculture are extremely rare events. Clearly, the UK (top left panel) was the first country to experience substantial structural change, with a labor share in agriculture below $50 \%$ as early as 1800 . At that time, the U.S. agricultural share was still above $75 \%$. Countries that started the process of structural change later tended to experience a faster pace of migrations. The difference in the speed of change is particularly clear when comparing the European early starters in the top right panel to the European late starters in the bottom left panel. When the latter started their transformations, the former already had very low labor shares in agriculture. Nonetheless, the late starters experienced much faster reallocations and nowadays their agricultural labor shares are not far from those of the earlier starters. The fastest change was experienced by South Korea and Japan.

Similar patterns emerge from the descriptive statistics summarized in Table 1. While 
Table 1: Descriptive statistics: structural change

\begin{tabular}{cccccc}
\hline \hline & \multicolumn{5}{c}{ Average annual change in share of employment in agriculture } \\
\cline { 2 - 6 } & whole sample & up to 1939 & after 1939 & $\begin{array}{c}\text { after 1939 } \\
\text { (countries with } \\
\text { pre-1939 data) }\end{array}$ & while $L^{A}>0.1$ \\
\hline mean change & -0.434 & -0.320 & -0.645 & -0.530 & -0.465 \\
$\quad \%$ pts) & $(0.456)$ & $(0.382)$ & $(0.508)$ & $(0.376)$ & $(0.484)$ \\
mean rate of & -1.847 & -0.796 & -3.788 & -3.575 & -1.502 \\
change $(\%)$ & $(1.908)$ & $(0.803)$ & $(1.835)$ & $(1.716)$ & $(1.723)$ \\
fraction $<0$ & 0.959 & 0.938 & 1.000 & 1.000 & 0.952 \\
\hline observations & 148 & 96 & 52 & 44 & 125 \\
countries & 13 & 12 & 8 & 7 & 13 \\
\hline \hline
\end{tabular}

Notes: Computed using 5-year moving averages of the variables for period where both price and labor share data is available. Standard errors in parentheses. The mean rate of change is the mean annualized $\%$ change. The mean change is in percentage points.

the standard deviation in the pooled data is substantial, virtually all episodes consist of migrations out of agriculture. On average over the whole sample, the agricultural labor share has dropped by 0.4 percentage points per year. This translates into a rate of decline of that share of $1.8 \%$ per year. At this rate it takes around 60 years to reduce the agricultural labor share from $60 \%$, the average labor share at the beginning of our sample, to 20\%. Structural change was slower before World War II (average annual change of -0.3 percentage points or a rate of change of $-0.8 \%)$ and faster afterwards (-0.6 percentage points or $-3.8 \%$ ). This tendency holds even when we restrict our sample to those industrialized countries for which pre-war data is available.

The first two columns of Table 2 present the average annual change and the average annual growth rate of the labor share in agriculture at the country level. It is clear that the variation across countries is substantial. While part of this is due to differences in data coverage across countries, most of it remains when computing the same statistics for smaller, balanced panels ${ }^{9}$ As was already evident in Figure 1, the late starters, perhaps

\footnotetext{
${ }^{9}$ In constructing balanced panels, there is a tradeoff between the number of countries and the overall number of observations that can be included. The most encompassing balanced panels cover seven countries over either 1860 to 1900 or 1890 to 1930. Clearly, the unbalanced panel with its much larger coverage is much more informative. In the 1860-1900 balanced panel, there is about half as much cross-
} 
Table 2: Descriptive statistics for historical data: Structural change and the change in the relative price of manufactures by country

\begin{tabular}{lcccc}
\hline \hline country & $\begin{array}{c}\mathrm{d} L^{A} \\
(\% \mathrm{pts})\end{array}$ & $\begin{array}{c}g\left(L^{A}\right) \\
(\%)\end{array}$ & $\begin{array}{c}g(p) \\
(\%)\end{array}$ & data coverage \\
\hline Belgium & -0.38 & -1.40 & -0.26 & $1846-1946$ \\
Canada & -0.50 & -2.59 & -0.10 & $1890-1970$ \\
Finland & -0.55 & -2.08 & -0.22 & $1880-2000$ \\
France & -0.20 & -0.42 & -0.33 & $1856-1911$ \\
Germany & -0.29 & -0.69 & -0.69 & $1871-1907$ \\
Italy & -0.14 & -0.24 & 0.34 & $1871-1911$ \\
Japan (1880-1930) & -0.66 & -1.02 & -0.40 & $1880-1930$ \\
& -0.84 & -4.88 & -2.42 & $1960-1990$ \\
Netherlands & -0.14 & -0.38 & -0.69 & $1820-1910$ \\
South Korea & -1.28 & -4.84 & -3.25 & $1965-2005$ \\
Spain & -0.23 & -0.40 & -0.15 & $1860-1950$ \\
Sweden & -0.48 & -2.08 & 0.12 & $1850-2000$ \\
UK & -0.29 & -1.48 & 0.20 & $1820-1900$ \\
USA & -0.38 & -1.85 & 0.25 & $1820-1999$ \\
\hline \hline
\end{tabular}

Notes: Computed using 5-year moving averages of the variables for period where both price and labor share data is available. All changes are annualized. For Japan, there are only two disjoint series for the relative price, so we treat the two periods separately. $d$ denotes a difference, $g(\cdot)$ a growth rate.

with the exception of Spain and Italy, experienced the fastest rates of structural change while France, Germany, Italy and the Netherlands had a much slower, drawn-out process.

\subsection{The relative price and structural change}

Table 3 shows descriptive statistics for changes in the relative price of manufactures. The average change in the relative price is slightly negative, an average decrease of less than one third of a percentage point per year. Around half of the observations fall on each side of zero, with a substantial standard deviation. For all countries taken together, the relative price declines more quickly after World War II. Here, however, sample composition

country variation in structural change as in the unbalanced one, while in the 1890-1930 one, there is almost as much as in the unbalanced panel. 
matters. Considering only those countries for which we also have data for the period before 1939, a pattern similar to that observed in the U.S. emerges: the relative price of manufactures falls before World War II and increases afterwards.

Table 3: Descriptive statistics: the relative price of manufactures

\begin{tabular}{cccccc}
\hline \hline & \multicolumn{5}{c}{ Annualized \% change in the relative price of manufactures } \\
\cline { 2 - 6 } & whole sample & up to 1939 & after 1939 & $\begin{array}{c}\text { after 1939 } \\
\text { (countries with } \\
\text { pre-1939 data) }\end{array}$ & while $L^{A}>0.1$ \\
\hline mean rate of & -0.279 & -0.161 & -0.498 & 0.011 & -0.595 \\
change (\%) & $(2.303)$ & $(1.692)$ & $(3.142)$ & $(2.921)$ & $(2.229)$ \\
fraction $<0$ & 0.493 & 0.510 & 0.462 & 0.386 & 0.552 \\
\hline observations & 148 & 96 & 52 & 44 & 125 \\
countries & 13 & 12 & 8 & 7 & 13 \\
\hline \hline
\end{tabular}

Notes: Computed using 5-year moving averages of the variables for period where both price and labor share data is available. Standard errors in parentheses. The mean rate of change is the mean annualized $\%$ change.

In the light of equation $(9)$, the fact that the average change in the relative price is slightly below zero suggests that non-agricultural technological change has outpaced its agricultural counterpart, again echoing the U.S. experience before World War II. It is also obvious from the third column of Table 2 that in Japan and Korea, where the move out of agriculture was particularly fast, the relative price of manufacturing goods plummeted, suggesting that improvements in manufacturing productivity were the main driver of the process there. These conclusions would hold only more strongly if the change in the relative price was overstated due to failure of price indices to account for quality improvements, which arguably are larger for manufactures than for agricultural goods.10

\footnotetext{
${ }^{10}$ As discussed in footnote 5 the relationship between labor allocations and relative prices (productivities) would be different in an open economy. Nonetheless, there are two reasons that make us believe that the close economy assumption is a reasonable approximation for the countries and periods under consideration. First, trade in agricultural products was very limited. For instance, despite being the main grain exporter in the late 19th century, U.S. grain exports amounted to less than $10 \%$ of the quantity produced (Getreidehandel, -Produktion und-Preise 1907). Second, relative prices do not co-move very much across countries. While most of the 23 pairwise correlation coefficients for changes in the relative prices that we can compute are positive, only three are statistically significant at the $10 \%$ level, and of these only
} 
In order to explore the determinants of structural change more formally, we regress the rate of change in the share of labor in agriculture in each country on the log of the relative price in that country and a country specific intercept. Empirically, this specification is motivated by the fact that we cannot reject that the agricultural share follows a random walk with country-specific drift. Its growth rate and the relative price are stationary.11 Theoretically, the rate of change of the agricultural labor share is a function of the aggregate rate of technological change, which is unobserved, and of its composition, about which the relative price contains information. The country fixed effects capture the average effect of aggregate technological change at the country level. This is important since the evidence presented in Table 2 points to important variations in the speed of structural change across countries. The coefficient on the relative price shows whether the composition of technological change has an effect on the speed of structural change. Finally, given our focus on the process of development, we restrict our analysis to the period where the share of employment in agriculture exceeds one tenth 12 This approach is preferable to limiting the time period under consideration since it preserves more observations. The resulting regression equation is

$$
g\left(L_{i t}^{A}\right)=\alpha_{i}+\beta \ln p_{i t}+\epsilon_{i t}
$$

where we compute the growth rate of the labor share in agriculture as the annualized growth rate between two consecutive observations.

A positive coefficient $\beta$ in this regression implies that decreases in the relative price are associated with faster than average decreases in the agricultural labor share. A negative coefficient implies that it is increases in the relative price which are associated with faster structural change. It then follows from equation (9) that a positive coefficient indicates that the labor pull channel has a stronger effect on the structural transformation than

two are larger than 0.5. If trade was an important determinant of the relative price (and therefore of the labor allocation) then we would expect much higher price correlations. The low importance of trade in agricultural output is in line with what Gollin, Parente and Rogerson (2007) document for poor countries nowadays.

${ }^{11}$ We use the panel unit root test recommended by Bond, Nauges and Windmeijer (2005) and Hall and Mairesse (2005), using 10-year lags to maximize the number of observations. Unlike most other panel unit root tests, this one can be applied to our data despite the somewhat irregular structure that is unavoidable when combining historical data across countries. The order of integration of the variables that we find could arise if the productivity of each sector is a random walk. The agricultural share could inherit this property, while the relative price, which depends on the productivity ratio, need not.

${ }^{12}$ This threshold was reached by the UK as soon as 1891, by Canada in 1951, and by the U.S. in 1955 . 
the labor push channel. As discussed above, a negative coefficient leaves several possible interpretations. While the statistics on changes in the relative price presented in Table 3 contain information on the prevalence and frequency of the two channels, the regression thus captures additional information on their relative strength.

Table 4 presents the basic regression results. The coefficient on the relative price is positive and strongly significant across specifications suggesting that in our sample, the labor pull effect affects the labor allocation more strongly than the labor push effect. In a model with limited labor mobility, labor reallocation would lag behind the relative price adjustment. This scenario is explored in the second columm of Table 4, which uses the lagged log relative price as a regressor. The sign, size, and significance of the coefficient are essentially unaffected by this change. The estimates reported in the third column suggest that structural change accelerates as the labor share in agriculture falls - this corresponds to the speeding up of the structural transformation after 1939 that was already visible in the descriptive statistics in Table 1. Still, the sign of the coefficient on the relative price is not affected by the introduction of the lagged agricultural share, suggesting once more that changes in non-agricultural technology have been the main driver behind the process of structural change in our sample.

These results are robust to changes in the specification and in the data selection rules. First, an interaction of the price and the lagged share is not significant. (Results not reported.) A quantile regression with the same specification as column 1 also yields estimates that barely change across quantiles of the dependent variable. Hence, the "pull" channel has a stronger effect on the labor share at all stages of the structural transformation. Results are also robust to the exclusion of individual countries, or to setting the agricultural share threshold for inclusion in the sample at $5 \%$ or at $15 \%$ (instead of 10\%) 13

The evidence reported in this section suggests that labor pull - increases in nonagricultural technology - has been the main driver behind the large migrations out of the agricultural sector that began more than two centuries ago in the UK. First, since the average change in the relative price in our sample is slightly negative, equation (9)

\footnotetext{
${ }^{13} \mathrm{An}$ interaction of the relative price with a dummy indicating whether the price is measured as $p_{m} / p_{a}$ or as $p_{y} / p_{a}$ is not significant. Nor do results change when splitting the sample along these lines, with the exception of the relative price losing significance in the column 3 specification if the price is measured as $p_{y} / p_{a}$. This is not surprising as the split samples are much smaller.
} 
Table 4: Regression results: the relative price and changes in the fraction of employment in agriculture

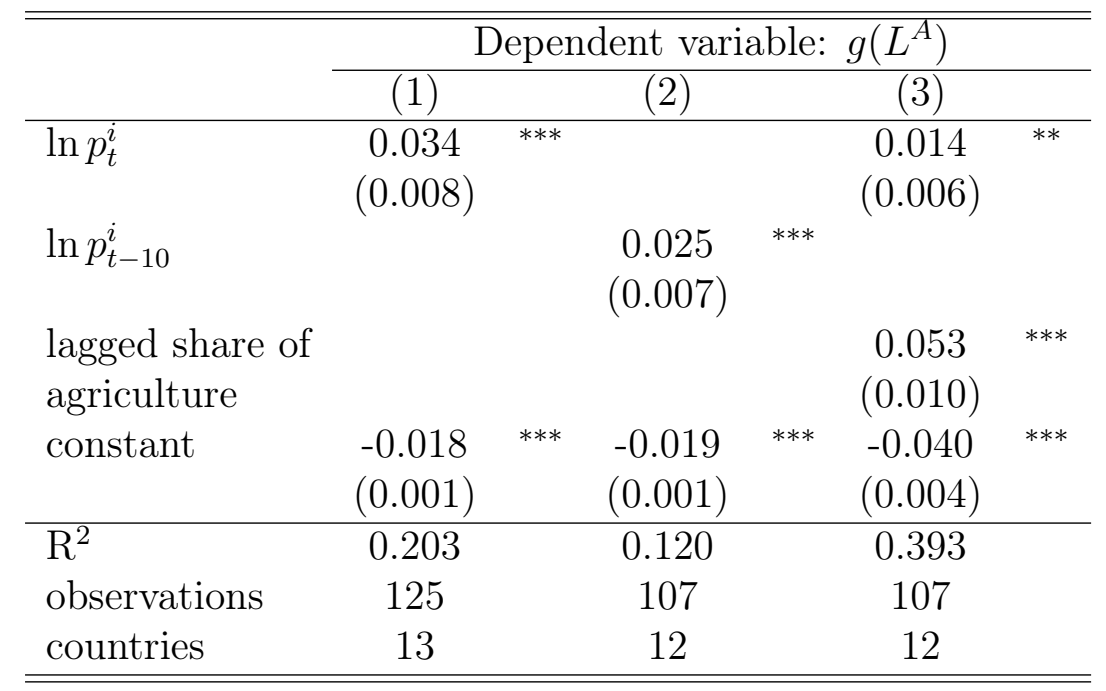

Notes: The dependent variable is the growth rate of the labor share in agriculture (average yearly growth rate between an observation and the previous observation). Variables are 5-year moving averages if data is at a higher frequency. Only observations where the labor share in agriculture is at least $10 \%$ are included. The regression includes country fixed effects. Robust standard errors (clustered at country level) in parentheses. Stars indicate statistical significance at the $90 \%\left(^{*}\right), 95\left(^{* *}\right)$ and $99 \%\left({ }^{* * *}\right)$ level, respectively. Lagged share of agriculture refers to a ten-year lag.

implies that non-agricultural technological change has marginally outpaced its agricultural counterpart. Second, our regression analysis complements this result, suggesting that in pull episodes, labor reallocation occurred at a faster pace than in labor push episodes.

Our results have important implications for modeling the process of structural change. On the one hand, models of structural change that rely on faster productivity growth in agriculture, such as Ngai and Pissarides (2007), seem to be at odds with most of the the pre-World War II evidence. On the other hand, models of structural change that restrict non-homotheticities in preferences to food consumption, such as Gollin et al. (2002), seem to miss non-agricultural technological progress as an important driver of structural change. Finally, our results cast some doubts on some of the policy recommendations derived using modeling strategies that neglect the crucial role played by non-agricultural productivity in the process of structural change and economic development. 


\section{Conclusions}

Recent years have seen a renewed interest in the role of agriculture in the process of development and structural change, motivated by the large role agriculture still plays in today's poor economies and by its importance for their aggregate productivity. Yet, there has been and still is a substantial debate about the relative roles played by agricultural and non-agricultural productivity in the structural transformation out of agriculture. The goal of this paper was to shed some light on this debate by examining the experience of countries that completed this transformation.

We presented a simple model consistent with the two crucial observations associated with the process of structural change: a secular decline in the share of the labor force devoted to agriculture and a decreasing weight of agricultural output in national product. We used this framework to explore the theoretical implications of the "labor push" and "labor pull" hypotheses that point to technological progress in agriculture and manufacturing, respectively, as the main driver of structural change. Then, using two data sets covering the structural transformation of 13 countries that completed that process, we explored the relative contribution of the two channels to the process of structural change.

This analysis yielded three main results. Firstly, both channels matter. In the case of the U.S., for instance, the "labor pull" channel dominated before World War I, with the "labor push" channel taking over after World War II. Secondly, on average, increases in non-agricultural productivity played a slightly larger role than those in agricultural productivity, pointing to the "labor pull" channel as a somewhat more important engine of structural change overall. Finally, we found that the agricultural labor share declined more when the productivity of manufacturing increased relative to that of agriculture. Overall, while the "labor push" channel matters at times, this evidence indicates that the "labor pull" channel was the main engine behind the massive reallocations of labor out of agriculture that began in the UK more than two centuries ago.

Our results are a crucial input for the growing theoretical work on structural change and may have important implications for the understanding and design of adequate development policies. 


\section{Appendix}

\section{A Basic results under CES preferences}

Assume preferences of our representative household are given by,

$$
U\left(c_{t}^{A}, c_{t}^{M}\right)=\left[(1-\eta)^{\frac{1}{\nu}}\left(c_{t}^{A}-\gamma\right)^{\frac{\nu-1}{\nu}}+\eta^{\frac{1}{\nu}}\left(c_{t}^{M}\right)^{\frac{\nu-1}{\nu}}\right]^{\frac{\nu}{1-\nu}}, \quad \alpha, \mu>0 ; \nu>0
$$

where $c_{t}^{A}$ and $c_{t}^{M}$ denote individual consumption of food and non-agricultural goods respectively, $\eta$ is the relative weight of non-agricultural goods in preferences and $\nu$ is the elasticity of substitution between the two types of goods. Under this preference specification (6) becomes

$$
\frac{\gamma}{A}=G\left(1-L_{t}^{M}\right)-\frac{1-\eta}{\eta}\left(\frac{A}{M}\right)^{\nu-1}\left[\frac{G^{\prime}\left(1-L_{t}^{M}\right)}{F^{\prime}\left(L_{t}^{M}\right)}\right]^{\nu} F\left(L_{t}^{M}\right) \equiv \phi^{C E S}\left(L_{t}^{M}, M, A\right),
$$

with

$$
\phi^{C E S}(1, \bar{M}, \bar{A})<\phi^{C E S}(0, \bar{M}, \bar{A})=G(1) ; \quad \phi_{L_{t}^{M}}<0 .
$$

On the one hand, the labor pull hypothesis requires $\phi_{M}^{C E S}>0$ which implies that the elasticity of substitution has to exceed unity, $\nu>1$. On the other hand, since $\operatorname{sign}\left(\phi_{M}^{C E S}\right)=-\operatorname{sign}\left(\phi_{A}^{C E S}\right)$, the labor push hypothesis requires that $\nu>1$ is not too large.14. If these two restrictions on the degree of substitutability between agricultural and non-agricultural goods hold, then all the results presented in Section 2 are valid under this preference specification that abstracts from $\mu$. In addition, as in Ngai and Pissarides (2007) differential productivity growth across sectors results in structural change even when the last source of non-homotheticity, $\gamma=0$, is removed 15 The intuition for this result is as follows. If the elasticity of substitution $\nu$ is above 1 , an increase in $M$ reduces the price of the non-agricultural good, and since both goods are good substitutes, induces a more than proportional increase in its demand that leads to a reallocation of labor to the non-agricultural sector. An increase in agricultural productivity reduces the price

\footnotetext{
${ }^{14}$ Specifically, we need $\gamma-\frac{1-\eta}{\eta}(\nu-1)\left[\frac{A G^{\prime}\left(1-L_{t}^{M}\right)}{M F^{\prime}\left(L_{t}^{M}\right)}\right]^{\nu} M F\left(L_{t}^{M}\right)>0$ This inequality holds for sufficiently small values of $\nu>1$.

${ }^{15}$ Nonetheless, when $\gamma=0$, only the labor pull hypothesis would be consistent with the path of migrations observed in the data. This is because our restrictions on $\nu$ imply that an increase in agricultural productivity leads to an increase in the share of labor employed in this sector.
} 
of food, causing opposing income and substitution effects. The substitution effect tends to raise food demand, while the income effect implies a reduced food expenditure share because the income elasticity of food is less than one. Our second restriction on the size of $v$ ensures that the income effect dominates the substitution effect and therefore an increase in $A$ is associated with a reduction in the agricultural labor force.

\section{B Data sources}

See Tables 5 and 6 .

Table 5: Historical data: sources and definitions

\begin{tabular}{|c|c|c|}
\hline country & $\begin{array}{l}\text { Share of employment } \\
\text { in agriculture }\end{array}$ & Relative price \\
\hline Belgium & Mitchell (2003, Table B1) & $\begin{array}{l}\text { Price indices for agricultural output and for total output, imputed } \\
\text { from the Groningen Growth and Development Centre Historical } \\
\text { National Accounts Database (Smits, Woltjer and Ma 2009), which } \\
\text { for Belgium mainly draws on Horlings (1996) }\end{array}$ \\
\hline Canada & $\begin{array}{l}\text { Historical Statistics of } \\
\text { Canada series } \# \mathrm{D} 1 \_7\end{array}$ & $\begin{array}{l}\text { General Wholesale Price Index, Fully and chiefly manufactured, } \\
\text { and Wholesale Price Index of Canadian farm products, Statistics } \\
\text { Canade }{ }^{a}\end{array}$ \\
\hline Finland & Mitchell (2003, Table B1) & $\begin{array}{l}\text { Price indices for agricultural output and for total output, imputed } \\
\text { from the Groningen Growth and Development Centre Historical } \\
\text { National Accounts Database (Smits et al. 2009), which for Finland } \\
\text { draws on Hjerppe }(1989,1996)\end{array}$ \\
\hline France & Mitchell (2003, Table B1) & $\begin{array}{l}\text { Price indices for agricultural output and for total output, imputed } \\
\text { from the Groningen Growth and Development Centre Historical } \\
\text { National Accounts Database (Smits et al. 2009), which for France } \\
\text { draws on Toutain (1987) }\end{array}$ \\
\hline Germany & $\begin{array}{l}\text { 1871: Statistisches } \\
\text { Jahrbuch für das Deutsche } \\
\text { Reich (1974 [1880]), 1882- } \\
\text { 1939: Mitchell (2003, } \\
\text { Table B1) }\end{array}$ & $\begin{array}{l}\text { Wholesale price indices for agriculture and manufacturing, Jacobs } \\
\text { and Richter (1935) }\end{array}$ \\
\hline
\end{tabular}

\footnotetext{
${ }^{a}$ Farm products index constructed by linking two indices (1890-1934 and 1926-1970).
} 


\begin{tabular}{|c|c|c|}
\hline country & $\begin{array}{l}\text { Share of employment } \\
\text { in agriculture }\end{array}$ & Relative price \\
\hline Italy & Mitchell (2003, Table B1) & $\begin{array}{l}\text { Wholesale price index and Bread and Flour price index, Fenoaltea } \\
(2002 \text {, Table A.1) }\end{array}$ \\
\hline Japan & Mitchell (1998) & $\begin{array}{l}\text { 1874-1939: Price index of agricultural products and of manufac- } \\
\text { turing, Choki Keizai Tokei (Estimates of Long-Term Economic } \\
\text { Statistics of Japan Since 1868) (1967) } 1960-1980 \text { : Domestic Cor- } \\
\text { porate Goods Price Index and Agricultural Price Index, Statistics } \\
\text { Bureav }\end{array}$ \\
\hline Netherlands & $\begin{array}{l}\text { Smits, Horlings and van } \\
\text { Zanden (2000) }\end{array}$ & $\begin{array}{l}\text { Price indices for agricultural output and for total output, imputed } \\
\text { from the Groningen Growth and Development Centre Historical } \\
\text { National Accounts Database (Smits et al. 2009), which for the } \\
\text { Netherlands draws on various sources, in particular Smits et al. } \\
(2000)\end{array}$ \\
\hline South Korea & Mitchell (1998) & $\begin{array}{l}\text { Producer price indices for agriculture and manufacturing, South } \\
\text { Korean National Agricultural Cooperative Federation }{ }^{C}\end{array}$ \\
\hline Spain & Mitchell (2003, Table B1) & $\begin{array}{l}\text { Price indices for agricultural output and for total output, imputed } \\
\text { from the Groningen Growth and Development Centre Historical } \\
\text { National Accounts Database (Smits et al. 2009), which for Spain } \\
\text { draws on Prados de la Escosura (2003) }\end{array}$ \\
\hline \multirow[t]{2}{*}{ Sweden } & $\begin{array}{l}\text { Data compiled by Rod- } \\
\text { ney Edvinsson, Stock- } \\
\text { holm University, www. }\end{array}$ & $\begin{array}{l}\text { Price indices for agricultural output and for total output, im- } \\
\text { puted from Swedish Historical National Accounts, compiled by } \\
\text { Olle Krantz and Lennart Schön, available in Lund University }\end{array}$ \\
\hline & $\begin{array}{l}\text { historicalstatistics. } \\
\text { org }\end{array}$ & $\begin{array}{l}\text { Macroeconomic and Demographic Database http://www.ehl. } \\
\text { lu se/database/LU-MADD/National\%20Accounts/default.htm }\end{array}$ \\
\hline UK & Clark (2002, Table 3$)$ & $\begin{array}{l}\text { Price indices for Principal Industrial Products and for Agricultural } \\
\text { Products, Mitchell (1988) }\end{array}$ \\
\hline USA & $\begin{array}{l}\text { 1800-1900: Weiss (1992, } \\
\text { 1993), 1910-2000: U.S. } \\
\text { Department of Commerce } \\
\text { (1975, series D5 and D6); } \\
\text { Dennis and Iscan (2009) }\end{array}$ & $\begin{array}{l}\text { 1800-1913: Wholesale price indices for all commodities and for } \\
\text { farm products (series E52 and E53), U.S. Department of Com- } \\
\text { merce (1975, Warren and Pearson series), Hanes (1998) d 1913- } \\
\text { 1954: Wholesale price indices for industrial commodities and for } \\
\text { farm goods, U.S. Department of Commerce (1975, series E23, } \\
\text { E25); 1954-2001: Producer price indices for farm products and } \\
\text { industrial commodities, Council of Economic Advisers (2002, Ta- } \\
\text { ble B-67); Dennis and Iscan (2009) }\end{array}$ \\
\hline
\end{tabular}

\footnotetext{
${ }^{a}$ Pages 165, 195, 197, 200, 203, 207.

${ }^{b}$ Statistical Survey Department, Statistics Bureau, Ministry of Internal Affairs and Communications. Tables 22-1 and 22-10. Downloaded from http://www.stat.go.jp/english/data/chouki/index.htm.

${ }^{c}$ Data downloaded from http://kosis.nso.go.kr.

${ }^{d}$ Hanes extended the series to 1860-1990 using the same method underlying the Warren and Pearson indices.
} 
Table 6: Data coverage

\begin{tabular}{lccccc}
\hline \hline country & \multicolumn{2}{c}{ share of employment } & & \multicolumn{2}{c}{ relative price } \\
& \multicolumn{2}{c}{ in agriculture } & & & \\
\cline { 2 - 3 } \cline { 5 - 6 } & period & observations & & period & observations \\
\hline Belgium & $1846-1946$ & 10 & & $1835-1953$ & 107 \\
Canada & $1881-1970$ & 12 & & $1890-1970$ & 81 \\
Finland & $1880-2000$ & 12 & & $1860-2001$ & 142 \\
France & $1856-1936$ & 11 & & $1815-1938$ & 118 \\
Germany & $1871-1939$ & 7 & & $1792-1913$ & 122 \\
Italy & $1871-1971$ & 10 & & $1861-1914$ & 54 \\
Japan & $1872-1990$ & 14 & & $1874-2004$ & 59 \\
Netherlands & $1800-1913$ & 114 & & $1807-1939$ & 121 \\
South Korea & $1955-2006$ & 46 & & $1965-2006$ & 42 \\
Spain & $1860-2001$ & 13 & & $1850-1958$ & 109 \\
Sweden & $1850-2000$ & 151 & & $1800-2000$ & 201 \\
UK & $1800-1930$ & 14 & & $1800-1900$ & 101 \\
USA & $1800-2000$ & 103 & $1800-2000$ & 201 \\
\hline \hline
\end{tabular}

\section{The measure of the manufacturing price}

For some countries where no measure of the price of manufacturing goods is available, we use the GDP deflator relative to the price of agricultural goods. This Appendix shows that this measure changes with changes in relative productivity of the two sectors in the same way as the ideal relative price would.

For this, first derive the correct consumption-based aggregate price index. With nonhomothetic preferences, this requires some precision because the marginal expenditure needed to raise by one unit is not constant and therefore does not coincide with the average expenditure per unit of utility. (This distinguishes this setup from e.g. a setup with Dixit-Stiglitz preferences, where such a consumption-based price index is often used, and where the two concepts coincide.)

Let $P$ be the marginal expenditure needed to raise utility by one unit beyond $\bar{u}$ and 
$\bar{P}$ the minimum expenditure needed to reach utility $\bar{u} . \bar{P}$ solves the problem

$$
\begin{aligned}
& \min _{c_{a}, c_{m}} p_{a} c_{a}+p_{m} c_{m} \\
& \text { s.t. } \beta \ln \left(c_{a}-\gamma\right)+\ln \left(c_{m}+\mu\right)=\bar{u} .
\end{aligned}
$$

$P$ is the multiplier on the constraint. The first order conditions are

$$
\begin{aligned}
p_{m} & =\frac{P}{c_{m}+\mu} \\
p_{a} & =\frac{\beta P}{c_{a}-\gamma} .
\end{aligned}
$$

Plugging this into the constraint and solving for $P$ yields

$$
P=\beta^{-\frac{\beta}{1+\beta}}[\exp (\bar{u})]^{\frac{1}{1+\beta}} p_{m}^{\frac{1}{1+\beta}} p_{a}^{\frac{\beta}{1+\beta}} .
$$

Using this,

$$
\frac{P}{p_{a}}=\beta^{-\frac{\beta}{1+\beta}}[\exp (\bar{u})]^{\frac{1}{1+\beta}}\left(\frac{p_{m}}{p_{a}}\right)^{\frac{1}{1+\beta}} .
$$

Clearly, $\ln \left(P / p_{a}\right)$ varies proportionally with $\ln \left(p_{m} / p_{a}\right)$.

Obtain $\bar{P}$ by evaluating the objective function at the optimum:

$$
\begin{aligned}
\bar{P}=p_{m} c_{m}+p_{a} c_{a} & =(1+\beta) P-p_{m} \mu+p_{a} \gamma \\
& =(1+\beta) \beta^{-\frac{\beta}{1+\beta}}[\exp (\bar{u})]^{\frac{1}{1+\beta}} p_{m}^{\frac{1}{1+\beta}} p_{a}^{\frac{\beta}{1+\beta}}-p_{m} \mu+p_{a} \gamma \\
\frac{\bar{P}}{p_{a}} & =(1+\beta) \beta^{-\frac{\beta}{1+\beta}}[\exp (\bar{u})]^{\frac{1}{1+\beta}}\left(\frac{p_{m}}{p_{a}}\right)^{\frac{1}{1+\beta}}-\frac{p_{m}}{p_{a}} \mu+\gamma
\end{aligned}
$$

Then

$$
\frac{\partial\left(\bar{P} / p_{a}\right)}{\partial\left(p_{m} / p_{a}\right)}=\beta^{-\frac{\beta}{1+\beta}}\left[\left(\frac{\beta P}{p_{a}}\right)^{\beta} \frac{P}{p_{m}}\right]^{\frac{1}{1+\beta}}\left(\frac{p_{m}}{p_{a}}\right)^{\frac{1}{1+\beta}-1}-\mu=\frac{P}{p_{m}}-\mu=c_{m},
$$

which is strictly positive for all countries in the data.

Hence, $p_{y} / p_{a}$ moves in the same direction as $p_{m} / p_{a}$ no matter whether the historical price indices we use measure average or marginal expenditure. As a result, while it is not legitimate to compare levels of indices between countries using $p_{m}$ vs $p_{y}$, within-country changes in the relative price reflect changes in $p_{m} / p_{a}$, and thus changes in the sectoral productivities, no matter whether they are measured using $p_{m}$ or $p_{y}$. 


\section{References}

Bond, S., Nauges, C. and Windmeijer, F. (2005), 'Unit Roots: Identification and Testing in Micro Panels', cemmap Working Paper 7.

Buera, F. J. and Kaboski, J. P. (2009), 'The Rise of the Service Economy', NBER Working Paper 14822.

Caselli, F. (2005), Accounting for Cross-Country Income Differences, in P. Aghion and S. Durlauf, eds, 'Handbook of Economic Growth', North-Holland, Amsterdam.

Caselli, F. and Coleman, J. (2001), 'The U.S. Structural Transformation and Regional Convergence: A Reinterpretation', Journal of Political Economy 109, 584-616.

Chenery, H. and Syrquin, M. (1975), Patterns of development, 1950-1970, Oxford University Press, London.

Choki Keizai Tokei (Estimates of Long-Term Economic Statistics of Japan Since 1868) (1967), Vol. 8, Toyo Keizai Shinposha, Tokyo.

Clark, C. (1940), The conditions of economic progress, 3rd edn, Macmillan, London.

Clark, G. (2002), 'The Agricultural Revolution and the Industrial Revolution: England, 1500-1912', mimeo .

Cole, H. L. and Ohanian, L. E. (1999), 'The Great Depression in the United States from a Neoclassical Perspective', Federal Reserve Bank of Minneapolis Quarterly Review $23(1), 2-24$.

Cole, H. L. and Ohanian, L. E. (2002), 'The U.S. and U.K. Great Depressions through the Lens of Neoclassical Growth Theory', American Economic Review 92(2), 28-32.

Council of Economic Advisers (2002), Economic Report of the President, U.S. Government Printing Office, Washington, D.C.

Craig, L. A. and Weiss, T. J. (2000), 'Hours at work and total factor productivity growth in 19th century U.S. agriculture', Advances in Agricultural Economic History 1, 1-30.

Dennis, B. N. and Iscan, T. B. (2009), 'Engel versus Baumol: Accounting for Structural Change using Two Centuries of U.S. Data', Explorations in Economic History 46(2), 186-202.

Duarte, M. and Restuccia, D. (2010), 'The Role of the Structural Transformation in Aggregate Productivity', Quarterly Journal of Economics 125(1).

Fenoaltea, S. (2002), 'Production and Consumption in Post-Unification Italy: New Evidence, New Conjectures', Rivista di Storia Economica 18, 251-299.

Gallman, R. E. (1972), Changes in total U.S. agricultural factor productivity in the nineteenth century, in D. P. Kelsey, ed., 'Farming in the New Nation: Interpreting American Agriculture, 1790-1840', Agricultural History Society, Washington, D.C. 
Getreidehandel, -Produktion und -Preise (1907), in 'Meyers Großes KonversationsLexikon', Vol. 7, Bibliographisches Institut, Leipzig, pp. 761-767.

Gollin, D., Parente, S. and Rogerson, R. (2002), 'The Role of Agriculture in Development', American Economic Review 92(2), 160-164.

Gollin, D., Parente, S. and Rogerson, R. (2007), 'The food problem and the evolution of international income levels', Journal of Monetary Economics 54(4), 1230-1255.

Greenwood, J., Hercowitz, Z. and Krusell, P. (1997), 'Long-run implications of investmentspecific technological change', American Economic Review 87(3), 342-362.

Griliches, Z. (1957), 'Hybrid Corn: An Exploration in the Economics of Technological Change', Econometrica 25(4), 501-522.

Gylfason, T. and Zoega, G. (2006), The Road from Agriculture, in T. Eicher and C. Garcia-Peñalosa, eds, 'Institutions, Development, and Economic Growth', MIT Press, Cambridge, MA.

Hall, B. H. and Mairesse, J. (2005), Testing for Unit Roots in Panel Data: An Exploration Using Real and Simulated Data, in D. W. K. Andrews and J. H. Stock, eds, 'Identification and Inference for Econometric Models: A Festschrift in Honor of Thomas Rothenberg', Cambridge University Press, Cambridge, UK.

Hanes, C. (1998), Consistent Wholesale Price Series for the United States, 1860-1990, in T. J. Dick, ed., 'Business Cycles since 1820: New International Perspectives from Historical Evidence', Edward Elgar, Cheltenham, UK and Northampton, MA.

Hansen, G. and Prescott, E. (2002), 'Malthus to Solow', American Economic Review 92(4), 1205-1217.

Harris, J. and Todaro, M. (1970), 'Migration, Unemployment and Development: A TwoSector Analysis', American Economic Review 60(1), 126-142.

Heisenberg, W. (1972), Physics and Beyond, Harper \& Row, New York, NY.

Hjerppe, R. (1989), The Finnish Economy 1860-1985: Growth and Structural Change, Bank of Finland, Helsinki.

Hjerppe, R. (1996), 'Finland's Historical National Accounts 1860-1994: Calculation Methods and Statistical Tables', Publications of Finnish History 24.

Horlings, E. (1996), 'Estimates of Value Added in the Belgian Service Sector 1830-1953', Catholic University of Leuven Research Memorandum .

Houthakker, H. (1957), 'An International Comparison of Household Expenditure Patterns, Commemorating the Centenary of Engel's Law', Econometrica 25(4), 532-551.

Jacobs, A. and Richter, H. (1935), 'Die Grosshandelspreise in Deutschland von 1792 bis 1934', Sonderhefte des Instituts für Konjunkturforschung 37.

Kendrick, J. (1961), Productivity Trends in the United States, Princeton University Press, Princeton. 
Kongsamut, P., Rebelo, S. and Xie, D. (2001), 'Beyond Balanced Growth', Review of Economic Studies 68(4), 869-882.

Krugman, P. (1991), 'History versus expecations', Quarterly Journal of Economics 106(2), 651-667.

Kuznets, S. (1966), Modern economic growth, New Haven, CT: Yale University Press.

Laitner, J. (2000), 'Structural change and economic growth', Review of Economic Studies 67, $545-561$.

Lewis (1954), 'Economic Development with Unlimited Supplies of Labour', Manchester School 22, 139-191.

Magnac, T. and Postel-Vinay, G. (1997), 'Wage Competition between Agriculture and Industry in Mid-Nineteenth Century France', Explorations in Economic History 34(1), 1-26.

Matsuyama, K. (1992), 'Agricultural productivity, comparative advantage, and economic growth', Journal of Economic Theory 58(2), 317-334.

Matsuyama, K. (2009), 'Structural Change in an Interdependent World: A Global View of Manufacturing Decline', Journal of the European Economic Association 7(2-3), 478486.

Mitchell, B. R. (1988), British Historical Statistics, Cambridge University Press, Cambridge.

Mitchell, B. R. (1998), International Historical Statistics: Africa, Asia \& Oceania, 17501993, 3rd edn, Macmillan Reference, London and Stockton Press, New York.

Mitchell, B. R. (2003), International Historical Statistics: Europe, 1750-2000, 5th edn, Palgrave Macmillan, New York.

Ngai, R. and Pissarides, C. (2007), 'Structural Change in a Multi-Sector Model of Growth', American Economic Review 97(1), 429-443.

Nurkse, R. (1953), Problems of capital formation in underdeveloped countries, New York: Oxford Univ. Press.

Olmstead, A. L. and Rhode, P. W. (2001), 'Reshaping the Landscape: the Impact and Diffusion of the Tractor in American Agriculture, 1910-1960', Journal of Economic History 61(3), 663-698.

Prados de la Escosura, L. (2003), El Progreso Económico de España 1850-2000, Fundación BBVA, Bilbao.

Prescott, E. C. (1999), 'Some observations on the great depression', Federal Reserve Bank of Minneapolis Quarterly Review 23(1), 25-31.

Restuccia, D., Yang, D. and Zhu, X. (2008), 'Agriculture and Aggregate Productivity: A Quantitative Cross-Country Analysis', Journal of Monetary Economics 55(2), 23450. 
Rostow, W. (1960), The Stages of Economic Growth: A Non-Communist Manifesto, Cambridge, UK: Cambridge Univ. Press.

Schultz, T. W. (1953), The Economic Organization of Agriculture, McGraw-Hill, New York, NY.

Smits, J.-P., Horlings, E. and van Zanden, J. L. (2000), 'Dutch GDP and its Components 1800-1913', Groningen Growth and Development Centre Research Monograph 5.

Smits, J.-P., Woltjer, P. and Ma, D. (2009), 'A Dataset on Comparative Historical National Accounts, ca. 1870-1950: A Time-Series Perspective', Groningen Growth and Development Centre Research Memorandum 107.

Sokoloff, K. L. (1986), Productivity growth in manufacturing during early industrialization: evidence from the American Northeast, 1820-1860, in S. L. Engerman and R. E. Gallman, eds, 'Long-Term Factors in American Economic Growth', number 51 in 'Studies in Income and Wealth', University of Chicago Press, Chicago.

Statistisches Jahrbuch für das Deutsche Reich (1974 [1880]), Georg Olms, Hildesheim and New York.

Temple, J. R. W. and Woessmann, L. (2006), 'Dualism and cross-country growth regressions', Journal of Economic Growth 11(3), 187-228.

Toutain, J.-C. (1987), Le produit intérieur brut de la France de 1789 à 1982, Économies et Société, Grenoble.

U.S. Department of Commerce (1975), Historical Statistics of the United States: from Colonial Times to the Present (1970), Bureau of the Census, U.S. Government Printing Office, Washington, D.C.

Weiss, T. (1992), U.S. Labor Force Estimates and Economic Growth, 1800-1860, in R. E. Gallman and J. J. Wallis, eds, 'American Economic Growth and Standards of Living before the Civil War', University of Chicago Press, Chicago.

Weiss, T. (1993), 'Long-Term Changes in U.S. Agricultural Output Per Worker, 18001900', Economic History Review 46, 324-341. 